\title{
RESEARCH
}

\section{Excessive fluid intake as a novel cause of proteinuria}

\author{
William F. Clark MD, Claude Kortas MD MEd, Rita S. Suri MD MSc, Louise M. Moist MD MSc, \\ Marina Salvadori MD, Matt A. Weir MD, Amit X. Garg MD PhD, for the WEL Investigators
}

\section{ABSTRACT}

As part of a community screening study to assess the longterm health outcomes among residents of Walkerton, Ontario, after contamination of its municipal water supply by Escherichia coli $\mathrm{O}_{157}: \mathrm{H}_{7}$ and Campylobacter in 2000, we identified 100 adults who had proteinuria and polyuria but no medical history or medication use to explain their condition. Fifty-six of the 100 participants underwent both initial and confirmatory urine concentration tests, which showed that their urine osmolality could reach normal levels. We then instructed them to reduce their fluid intake to less than $2 \mathrm{~L} / \mathrm{d}$ for $\mathbf{1}$ week. The proteinuria and polyuria were largely reversed by this manoeuvre. We do not know at this time whether the proteinuria associated with excessive fluid intake in these otherwise healthy people will affect their kidney function in the long term.

Une version française de ce résumé est disponible à l'adresse www.cmaj.ca/cgi/content/full/178/2/I73/DCI

CMAJ 2008;178(2):173-5

W e are currently conducting a longitudinal population cohort study in the community of Walkerton, Ontario, to determine health outcomes after the municipal water supply was contaminated with $E s$ cherichia coli OI57: $\mathrm{H}_{7}$ and Campylobacter in 2000. ${ }^{1}$ Our study cohort of 4496 people represents about $50 \%$ of the community, and their demographic characteristics are similar to those of the whole community. ${ }^{2}$

As part of our initial assessment in 2002, we measured urine protein levels in 24-hour collections of urine from 2253 adults who later attended a follow-up clinic annually between 2003 and 2005. We measured the protein levels with a Vitros 950 autoanalyzer (Ortho-Clinical Diagnostics \% Inc., Rochester, New York) using the pyrocatechol dye procedure, ${ }^{3}$ with a coefficient of variation for the low control below $3.5 \%$ and a lower limit of sensitivity of $0.05 \mathrm{~g} / \mathrm{L}$. Of the 2253 people screened, I86I had urine creatinine levels within the sex-adjusted reference limits. ${ }^{4,5}$ They comprised II 99 who had neither proteinuria nor polyuria, 445 who had proteinuria without polyuria, 4 who had polyuria without pro- teinuria and 213 who had proteinuria with polyuria. Unexpectedly, in this last group, who had proteinuria (protein excretion $>0.20 \mathrm{~g}$ in 24 hours), polyuria (urine volume $>2.9 \mathrm{~L}$ in 24 hours) and seemingly normal kidney function (creatinine clearance rate $>60 \mathrm{~mL} / \mathrm{min}$ per $\mathrm{I} .73 \mathrm{~m}^{2}$ ), ${ }^{4}$ we found ioo participants ( $4.4 \%$ of the community sample) who had no explanation for their proteinuria. These roo people had no evidence of kidney disease, diabetes mellitus, hemolytic uremic syndrome or psychogenic polydipsia by self-report or medical chart audit. None had received lithium or diuretics, ${ }^{6}$ and only 28 had hypertension.

The roo participants had urine protein concentrations from 0.07 to $0.15 \mathrm{~g} / \mathrm{L}$, well above our lower limit of detection. In the 24-hour collections of urine, the mean amount of protein excreted was $0.43 \mathrm{~g}$ (standard deviation [SD] $0.2 \mathrm{I} \mathrm{g}$, $95 \%$ confidence interval [CI] $0.36-0.49 \mathrm{~g}$ ), and the mean volume of urine was $3.7 \mathrm{~L}$ (SD I.2 L, 95\% CI 3.3-4.I L). This group was similar to the overall cohort of 2253 adults in terms of age (mean 47 [range 15-72] and 47 [range 15-92] years, respectively), sex ( $68 \%$ and $6 \mathrm{I} \%$ women), history of hypertension $(28.0 \%$ and $35.2 \%)$ and gastroenteritis (61.0\% and $60.4 \%)$.

We attempted to discern the cause of the unexplained proteinuria and polyuria. Of the roo people, 63 agreed to confirmatory 24-hour urine collection to measure protein excretion, followed by a urine osmolality measurement after overnight water deprivation. The 24-hour confirmatory urine samples had a mean protein content of $0.40 \mathrm{~g}$ (SD $0.29 \mathrm{~g}$, $95 \%$ CI $0.30-0.49 \mathrm{~g}$ ) and a mean volume of $3.6 \mathrm{~L}$ (SD r.8 L, $95 \% \mathrm{CI} 3.0-4.2 \mathrm{~L}$ ). After the overnight water-deprivation test, we found that 39 of the 63 participants had a urine osmolality of more than $450 \mathrm{mOsm} / \mathrm{kg}$. Of the 24 whose urine was not concentrated to this level, 17 returned after another voluntary overnight water-deprivation test to undergo 8 hours of observed water deprivation. By the end of the 8 hours, we found that the urine was concentrated to a level greater than $450 \mathrm{mOsm} / \mathrm{kg}$ in all 17 cases (Table I), which meant that diabetes insipidus was unlikely. The baseline characteristics did

From the Department of Medicine (Nephrology), London Health Sciences Centre (Clark, Kortas, Suri, Moist, Weir, Garg), and the Division of Infectious Diseases, Children's Hospital of Western Ontario (Salvadori), University of Western Ontario, London, Ont. 
Table 1: Osmolality of serum and urine samples from 63 participants who had unexplained proteinuria and polyuria

\begin{tabular}{lccc}
\hline & No. of & & \multicolumn{2}{c}{ Osmolality, mOsm/kg } \\
\cline { 3 - 4 } Test & participants & Serum & Urine \\
\hline Overnight water deprivation $(n=63)$ & 39 & - & $451-1069$ \\
\hline $\begin{array}{l}\text { Concentrated urine } \\
\text { Unconcentrated urine }\end{array}$ & 24 & - & $59-450$ \\
\hline $\begin{array}{l}\text { Repeat overnight water deprivation followed } \\
\text { by 8-hour observed water deprivation }\left(n=17^{*}\right)\end{array}$ & & & \\
\hline Initial & 10 & $241-303$ & $460-821$ \\
\hline Hour 1 & 2 & $272-299$ & $458-587$ \\
\hline Hour 2 & 1 & 282 & 478 \\
\hline Hour 4 & 2 & $287-294$ & $472-511$ \\
\hline Hour 8 & 2 & $230-289$ & $456-492$ \\
\hline
\end{tabular}

*Seventeen of the 24 participants who initially had unconcentrated urine (osmolality $\leq 450 \mathrm{mOsm} / \mathrm{kg}$ ) agreed to undergo a repeat overnight water-deprivation test 1 week after the first, followed by an 8-hour observed water-deprivation test. The observed water-deprivation test ended as soon as patients demonstrated concentrated urine; the number of participants achieving this at each point is shown.

Table 2: Mean urine volume, protein and creatinine levels, and protein:creatinine ratio in 24-hour urine collection before and after voluntary intervention to reduce fluid intake among 56 participants with unexplained proteinuria and polyuria

\begin{tabular}{lccc}
\hline & \multicolumn{2}{c}{ Time of measurement; mean value (95\% confidence interval) } \\
\cline { 2 - 4 } Measurement & At baseline & Before intervention & After intervention \\
\hline Urine volume, $\mathrm{L}$ & $3.69(3.44-3.95)$ & $3.35(2.89-3.82)$ & $1.81(1.54-2.07)$ \\
Protein level, g & $0.41(0.36-0.45)$ & $0.38(0.31-0.46)$ & $0.16(0.12-0.20)$ \\
Creatinine level, mmol & $10.61(10.08-11.14)$ & $12.04(11.14-12.94)$ & $12.50(10.56-14.44)$ \\
Protein:creatinine ratio & $0.04(0.04-0.04)$ & $0.03(0.03-0.04)$ & $0.02(0.01-0.02)$ \\
\hline
\end{tabular}

not differ significantly between the 56 people who participated in the complete testing ( 39 who required only I test plus 17 who completed 2 tests) and the 44 people who did not participate in the complete testing.

The 56 participants were then asked to voluntarily reduce their total daily fluid intake to fewer than 8 large glasses $(<2.0 \mathrm{~L} / \mathrm{d})$ for I week, on the last day of which they provided another 24-hour urine sample. The mean urine volume following the voluntary water-reduction intervention decreased to I.8I L in 24 hours ( $95 \% \mathrm{CI} \mathrm{I.54-2.07} \mathrm{L),} \mathrm{and} \mathrm{the} \mathrm{amount} \mathrm{of}$ protein excreted decreased to a mean of $0.16 \mathrm{~g}$ in 24 hours (95\% CI 0.12-0.20 g) (Table 2). The mean urine creatinine level did not change significantly from the baseline level before or after the intervention (Table 2). The relation between urine volume and protein excretion was similar for the 56 participants regardless of whether they had had symptoms of gastroenteritis at the time of the water contamination in 2000.

When asked about their fluid consumption, the 56 participants indicated that they were drinking large volumes of fluid because they perceived it to be a healthy lifestyle choice. The water contamination and resultant temporary switch to bot- tled water may have led some to assume a habit of overconsumption. However, most said that their overconsumption preceded the water contamination. Although our participants did not fit the classic description of the compulsive water drinker, their attenuated concentration response did. ${ }^{7}$

Our unexpected finding of a $4.4 \%$ rate of proteinuria associated with polyuria in seemingly healthy people stemmed from observations that had been made during a communitybased screening program. The reversible nature of the proteinuria and polyuria after reduction of the total fluid intake to less than $2 \mathrm{~L} / \mathrm{d}$ makes any explanation other than voluntary excessive fluid intake unlikely. In a study of the effect of water loading on urinary albumin excretion in I8 healthy volunteers, Viberti and colleagues ${ }^{8}$ noted that water loading was associated with a short-lived but significant increase in urine albumin levels. We did not characterize the proteinuria, nor do we know at this time whether the reversible proteinuria associated with large fluid intake in these otherwise healthy people could affect their kidney function in the long term..$^{9-11}$ If the proteinuria was largely tubular in origin, owing to tubular washout, rather than glomerular in origin, one might pre- 
sume that progressive kidney injury would be less likely. ${ }^{9}$ Until such data are available from our longitudinal study, it may be advisable to discourage otherwise healthy people from consuming large volumes of fluid.

This article has been peer reviewed.

Competing interests: None declared.

Contributors: All of the authors contributed to the intellectual content of this report and take responsibility for the content. All approved the final version.

\section{REFERENCES}

I. The investigative report of the Walkerton outbreak of waterborne gastroenteritis, May-June, 200o. Owen Sound (ON): Bruce-Grey-Owen Sound Health Unit; 2000. Available: http://enve.coe.drexel.edu/outbreaks/WalkertonReportOct200o/REPORT Octoo.PDF (accessed 2007 Nov 7)

2. Garg AX, Macnab J, Clark W, et al. Long-term health sequelae following E. coli and Campylobacter contamination of municipal water - population sampling and assessing non-participation biases. Can J Public Health 2005;96:125-30.

3. Orsonneau JL, Douet P, Massoubre C, et al. An improved pyrogallol red-molybdate method for determining total urinary protein. Clin Chem I989;35:2233-6.

4. Couchoud C, Pozet N, Labeeuw M, et al. Screening early renal failure: cut-off values for serum creatinine as an indicator of renal impairment. Kidney Int I999;55:I878-84

5. Clark WF, Macnab JJ, Chen SJ, et al. Evaluation of GFR estimating equations in the general community: implications for screening. Clin J Am Soc Nephrol 2006;1:787-95

6. Garofeanu CG, Weir M, Rosas-Arellano MP, et al. Causes of reversible nephrogenic diabetes insipidus: a systematic review. Am J Kidney Dis 2005;45:626-37.

7. Barlow ED, De Wardener HE. Compulsive water drinking. Q J Med I959;28:235-58.

8. Viberti GC, Mogensen CE, Keen $\mathrm{H}$, et al. Urinary excretion of albumin in normal man: the effect of water loading. Scand J Clin Lab Invest I982;42:147-57.

9. Praga M, Morales E. Renal damage associated with proteinuria. Kidney Int SuppI 2002 Dec; $(82): 42-6$.

Io. Ruggenenti P, Gaspari F, Perna A, et al. Cross sectional longitudinal study of spot morning urine protein:creatinine ratio, 24 hour urine protein excretion rate, glomerular filtration rate, and end stage renal failure in chronic renal disease in patients without diabetes. $B M J$ I998;316:504-9.

II. Hebert LA, Greene T, Levey A, et al. High urine volume and low urine osmolality are risk factors for faster progression of renal disease. Am J Kidney Dis 2003;4I:962-7I.

Correspondence to: Dr. William F. Clark, Department of Medicine (Nephrology), London Health Sciences Centre, Rm. A2-343, 800 Commissioners Rd. E, London ON N6A 4G5; fax 519685-8047; william.clark@lhsc.on.ca

WEL (Walkerton E. coli Long-term) Investigators: William F. Clark, Rita S. Suri, Louise M. Moist, Amit X. Garg and John Howard, Department of Medicine (Nephrology), London Health Sciences Centre, London, Ont.; Marina Salvadori, Division of Infectious Diseases, Children's Hospital of Western Ontario, London, Ont.; and Douglas Matsell, Department of Pediatrics, University of British Columbia, Vancouver, BC 